Original Research Paper

\title{
Contribution of Remote Sensing in the Estimation of the Populations Living in Areas with Risk of Gully Erosion in Kinshasa (D.R. Congo). Case of Selembao Township
} \author{
${ }^{4}$ Mpinda T. Martin, ${ }^{5}$ Misilu Mia Nsokimieno Eric and ${ }^{6}$ Eléonore Wolff \\ ${ }^{1}$ Department of Geography, University of Lubumbashi, D.R. Congo \\ ${ }^{2}$ Department of Geosciences, University of Kinshasa, D.R. Congo \\ ${ }^{3}$ Center of Geological and Mining Survey, Kinshasa, D.R. Congo \\ ${ }^{4}$ Department of Natural Resources Management and Renewables, \\ Faculty of Agricultural Sciences, University of Lubumbashi, Congo \\ ${ }^{5}$ China University of Geosciences, China \\ ${ }^{6} I G E A T$, Université Libre de Bruxelles, Belgium
}

${ }^{1}$ Kayembe wa Kayembe Matthieu, ${ }^{1}$ Ngoy Ndombe Alain, ${ }^{2,3}$ Makanzu Imwangana Fils,

Article history

Received: 01-04-2016

Revised: 02-06-2016

Accepted: 06-06-2016

Corresponding Author:

Kayembe wa Kayembe

Matthieu

Department of Geography,

University of Lubumbashi,

D.R. Congo

Tel: +24399022 15 42;

+243841020526

Email: kayembematthieu@yahoo.fr

\begin{abstract}
This paper proposes a methodology combining very high spatial resolution satellite image, GIS and field surveys to estimate the number of people living in areas at (high) risk of landslides or gully erosion in Selembao (Kinshasa). It also gives their socio-economic characteristics. Results show that 185,000 out of the 314,699 inhabitants estimated in Selembao (58.3\% of the population) live in areas at high risk of gully erosion. There are in the spontaneous neighborhoods built on steep areas (slope $>10 \%$ ). The study of the socio-economic characteristics shows that these inhabitants belong to the modest socio-economic category (selfmade bricklayers, seller at the markets and street traders selling food stuff). The level and nature of their income led them to have residential integration strategic restricted to hazardous areas where land prices and rents are more attractive.
\end{abstract}

Keywords: Remote Sensing, Gully Erosion, GIS, Estimation of Population, Hazardous Area, Kinshasa

\section{Introduction}

The knowledge of the size of the population is a pressing need in several areas, including transport, health (public), education, housing (residential), economic planning, taxation (capitation), etc. (Romaniuk, 1967).

The United Nations recommend us to make a census once every 10 years. But given its cost, there are few African countries that meet this requirement. Some countries organize it at irregular time intervals.

Since its independence (in 1960) until today, the DRC has organized general population censuses in 1970 and 1984 only. National population data result from simple projections from the Institut National de la Statistique/National Statistics Institute (INS). It is true that regional censuses were often organized. But the figures on the population of townships are not always reliable because of the quality of the census takers, deficient census methods and the civil state offices not working properly (Kayembe wa Kayembe et al., 2009).

These projections of the Congolese INS do not make it possible to obtain the right number of people living in areas at risk of landslides and gully erosion in Kinshasa. However, these areas involve a large population. In 2004, for example, over $50 \%$ of the Kinshasa population $(3,441,506$ inhabitants/7,017,000) lived in townships considered to be at (high) risk of gully erosion or landslide, especially Makala, Lemba, KimbansekeNgaliemaSelembao, Mont Ngafula and Kisenso (DSRP, 2005). Yet all the territories of these townships are not located on the areas at (high) risk of gully erosion or landslide. Indeed, for the municipalities of Makala, Lemba, Selembao and Kimbasenke, the risk areas are in the southern part, while Ngaliema and Kisenso are completely on hazardous areas. 
Every year, all these towns are facing real environmental problems related to the gully erosion phenomenon. It increases quickly in number. There were 195 gullies in 1970 over the entire city against 334 identified ravines on World view 1 image in 2010 on the entire city (Makanzu Imwangana et al., 2014). It also increases in size of gullies. For example, the gully of Mataba successively reached 14.4 hectares in 2007 , 16.8 hectares in 2009 and 43.9 hectares in 2010 (Kayembe wa Kayembe, 2012). Moreover, there is a spatial deployment: All areas of the south-east and west of Kinshasa are affected by this phenomenon.

This gully erosion phenomenon causes significant material losses (houses, roads, school buildings, clinics, ...are destroyed) and human ones (death during the collapse of houses) (Wouters and Wolff, 2010). Indeed, the ravines have destroyed 965 residential houses between 1999 and 2010, 5 schools (completely or partially), 5 health centers and 16 other health centers have been at risk to be destroyed in 2010. A hundred of roads/tracks have been cut (Makanzu Imwangana et al., 2015). Transportation, electricity and water infrastructure have been destroyed as well as main sewers for water runoff. The ravines have caused the silting of rivers and homes at the foot of the hill and killed about 150 people between 1970 and 2010.

Hazardous areas of Kinshasa were specified by Van Caillie (1997). According to this author, they are characterized by slopes likely (from 12\%) to trigger the gully erosion or landslide in this city. Now these slopes are not visibly observable by census takers to determine the number of people living in areas at risk. Hence the first objective of this paper is to define a methodology combining very high spatial resolution satellite image, GIS and field surveys to estimate the number of people living in these areas at risk of landslides or gully erosion.

\section{Study Area}

Selembao township is located in the southern hilly area, except for two districts (MwanaTunu and Nkulu) in the north which are located in the plain. It is characterized by an almost spontaneous urbanization, except for some southern districts (Cité Verte and Habitat). In fact, it is a post-independence township. It was created, like other townships after a recent extension according to Flouriot et al. (1975) typology, from the watchword of political leaders inviting their activists (New and old urban city dwellers) to take a building plot in a context whereby these leaders wanted to constitute their electorate, ahead of the first democratic elections which were to take place in 1960 (De Saint Moulin, 2010).
Apart from Cité Verte, which is well equipped with roads and a sewer system, other neighborhoods are built on a land not laid out and therefore not equipped. Gully is much more developed in the central and southern areas of the concerned township (Fig. 1).

Due to the high rate of average annual growth (5\% between 1984 and 2004), the need for housing is strong there. Then, for the development of housing, heads of circuses and steep valleys of Bumbu and Lubudi rivers are not discarded. The ongoing urbanization in this township tends to filling interstitial spaces constituted of no aedificandi areas.

\section{Materials and Methods}

We chose a methodology which combines very high spatial resolution satellite image with the zonal approach, a GIS and field survey to estimate the amount of people living in risk area in Selembao. It has the advantage of being less expensive compared to the census ( $\mathrm{Lu}$ et al., 2002) and aerial photography (Yagoub, 2006). However, it requires the knowledge of the size of the households as the counting of housing units on aerial photography (Baudot, 1993 ; Hsu, 1971; Lo, 1985; Watkins and Morrow, 1985).

In Sub-Saharan Africa, this methodology was used by Yossi et al. (2002) and the POPSATER (2011) to estimate the population of Yaounde (Cameroon) in 2000 and of Lubumbashi (D.R Congo) in 2009.

The zonal approach is a subdivision of the region morphologically homogeneous classes (or types of district) according to certain criteria, while the approach based on the pixel consists of a satellite image processing.

\section{Determination of the Morphological Classes and Typology of the District}

We indeed have used a false color composite image colors GeoEye-1 (spatial resolution: $2 \mathrm{~m}$ ) to define morphologically homogeneous areas. Five classes of morphological zones (Table 1 and Fig. 2) were determined through visual interpretation based on the following parameters: Built-up density, vegetation density and roads structuration. Each morphological class was coded with a succession of three numbers from 1 to 3 for each parameter of homogeneity. 3 is used for high density, 1 for low housing and vegetation density. Unlike the first two parameters, only two digits are assigned to the road: 1 and 2 to express structured road (1) or unstructured (2). For example, the class 311 means high built-up density, low density of vegetation, structured road. 
Table 1. Morphological classes codes and types of neighborhoods

\begin{tabular}{ll}
\hline Morphological classes codes & Types of neighborhoods \\
\hline 311 & Old neighborhoods densely built on the top of the hill \\
211 & Rich neighborhoods \\
332 & Spontaneous settlements on steep slopes \\
112 & Self-built neighborhoods on ongoing urbanization \\
222 & Quarters in the process of densification \\
\hline
\end{tabular}

(Source: Data collected on the field work, 2010)

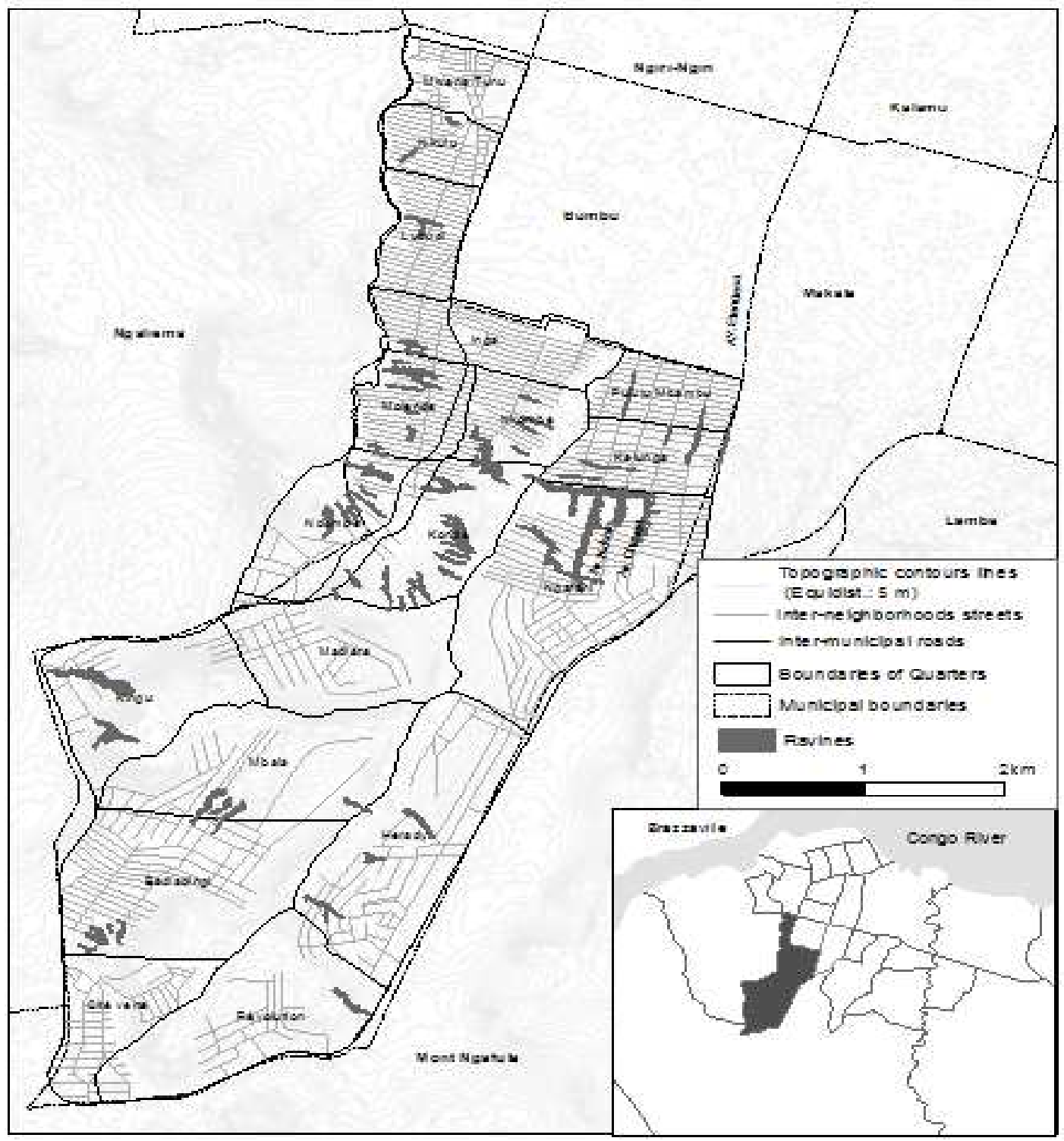

Fig. 1. Study area location (Source: Topographic contours lines are derived from DEM produced in 2010 by Philippe Trefois in Geomorphology and Remote Sensing Service of the Royal Museum for Central Africa)

The choice of these parameters used to create morphological classes lies in the fact that their combination allows interpreting the structure of the Selembao Township. First of all, the first two parameters (built-up and vegetation density are complementary) and they are used to observe the density of the built-up, which increases in areas with a high density of vegetation. The latter correspond to areas affected by gully erosion as the vegetation is used as a means to fight against gully erosion (Delbart and Wolff, 2002).

The low built-up density is generally observed in wealthy neighborhoods. It is explained by the large size 
of housing and plots. The only exception is the selfconstruction areas in course of urbanization where the density is still low but the sizes of housing and plots are not different from those observed in spontaneous settlements on steep slopes.

The last parameter (road network) allows a second interpretation of the built-up density: The road network is structured in wealthy neighborhoods, while it is less structured in vulnerable informal settlements in the gully area.

\section{Field Survey}

We conducted a systematic socio-economic questionnaire survey in 40 randomly selected islets in the township of Selembao (Fig. 3). At first, systematic plot survey was conducted in 40 islets. A total of 797 plots, or 1.409 households were contacted during the plot statement. During this survey, the number of households living in each plot was recorded and by the same token the size of each household was measured. Secondly, from this index card (form) of fragmented statement, we selected in every islet 10 different households. The questionnaire surveys were conducted with 151 selected households. The survey questions focused firstly on household members (age, sex, information on qualifications and employment status, etc.), its habitat and the level of the other equipment (materials for construction, housing comfort, etc.). For this paper, we have used only the data that will characterize the population's socioeconomic point of view and to estimate the population living on steep slopes.

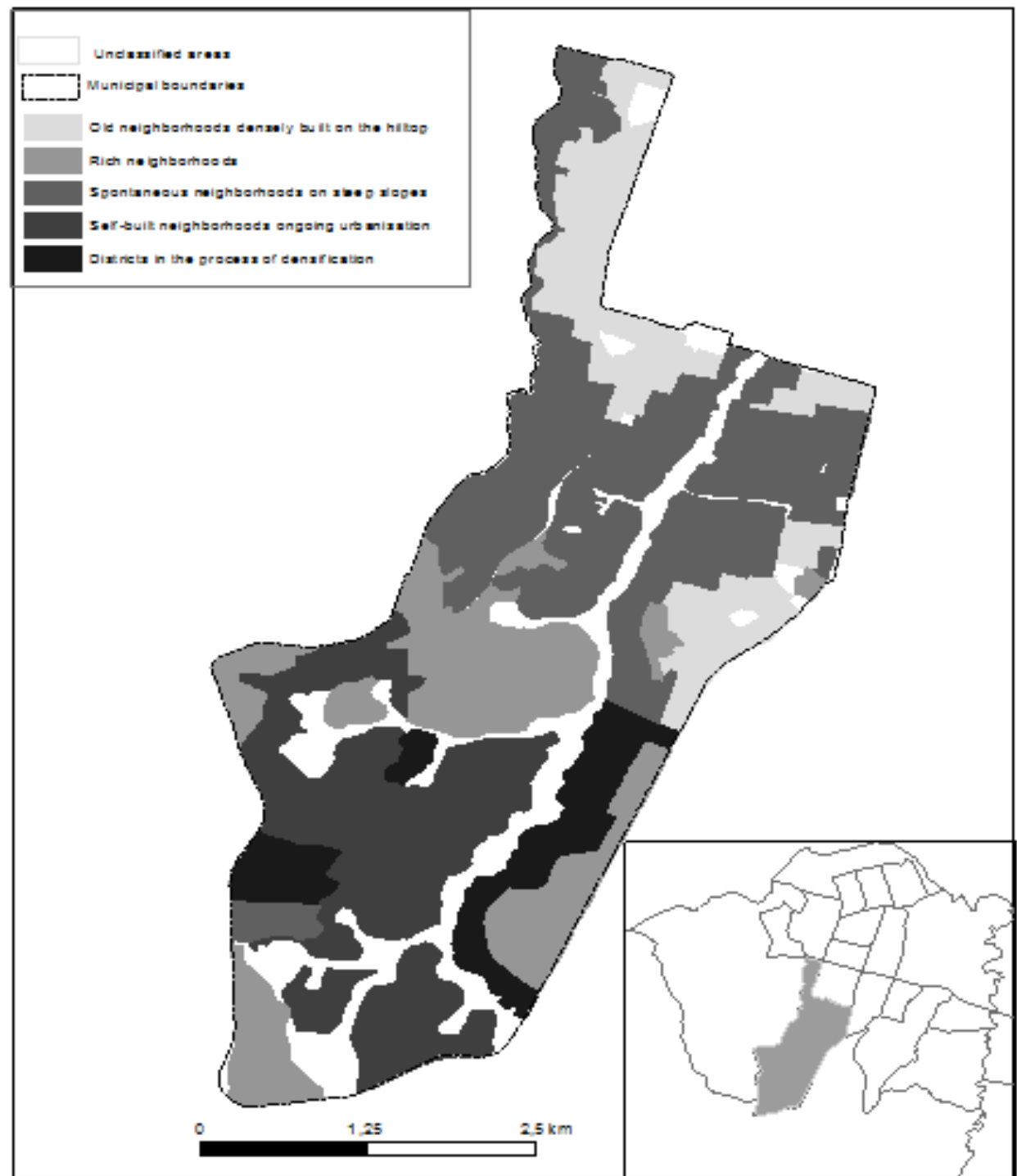

Fig. 2. Selembao morphological classes according to the road network, built-up and vegetation density (Source: GeoEye-1 image of june 30,2010 ) 


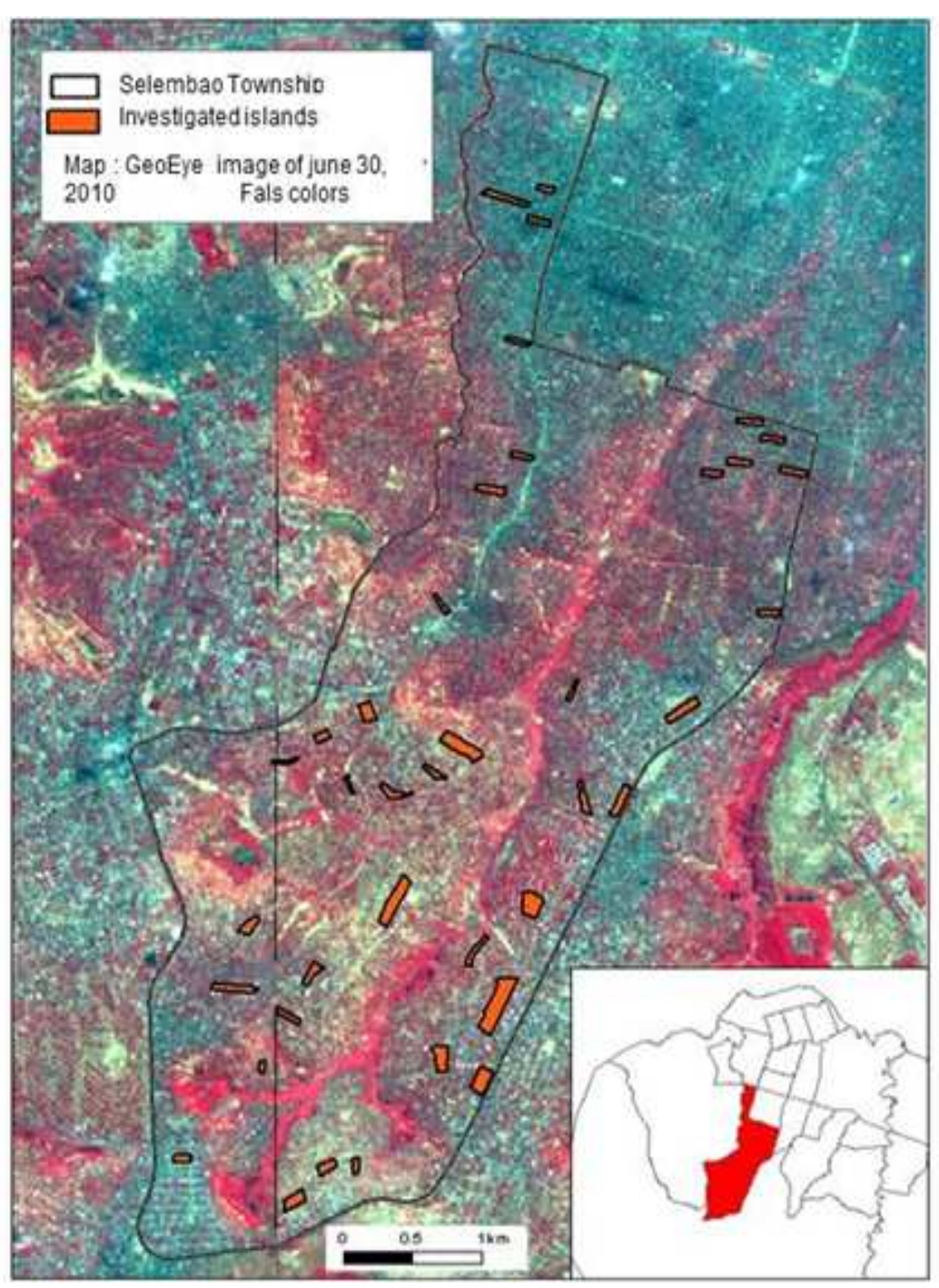

Fig. 3. Investigated islets in Selembao in 2010

\section{Using the GIS}

We used two techniques in a GIS to estimate the population living in areas of high slopes in Selembao. For the first technique, we calculated the slopes after cutting a digital terrain model (DEM) to the size of the municipality of Selembao through GRASS software. The slope map has been smoothed using a low-pass window of $9 \times 9$. The slopes were reclassified into three categories in relation to gully erosion $(<10 \%, 10-15 \%$ and $>15 \%)$ as defined by Van Caillie (1997). The vector file of islets was rasterized and a statistical overlap between the slope map and raster islets of respondents was carried out in the r.report GRASS $^{\circledR}$ software module.

From the table generated by this module (r.report), we calculated the size of the islets surveyed as they belong to a specific category of slopes and summed the relevant populations sampled. These two variables were used to calculate the density of the population sampled by category slopes. This sampled density has been multiplied by the area occupied in order to obtain the number of people living on the different categories of slopes.

For the second technique, we applied a statistical overlap between the morphological classes raster and the surveyed islets. Then we calculated the area occupied by the sample population islets according to their belonging to the morphological classes. Then we applied a simple rule of three to calculate the total population in a morphologically homogeneous class. Finally, we obtained the total population by summing the population of each morphological class.

The estimation of the population of the township of Selembao by these two methods was made with the aim of verifying if the size of the population was function of the slope or types of districts (or the morphologically homogeneous classes). 


\section{Results}

Size of the Population in Selembao Areas at Risk of Landslide

Selembao population was estimated to amount to 314,690 inhabitants in 2010 on the basis of themethod of calculation founded on the relief, i.e., the zones with weak slope $(<10 \%)$, strong slope $(10-15 \%)$ and very strong slope $(>15 \%)$ (Table 2). This categorization of the slopes is based on work of Van Caillie (1997) on the vulnerability of the soil to gully erosion or landslide in Kinshasa.

From Table 2, one can notice that 131,821 out of the 314,690 inhabitants of Selembao, as estimated earlier, are installed on zones with weak slopes $(<10 \%)$. These areas correspond to the zones at less risk of gully erosion or landslide. 69,945 out of 314,690 inhabitants occupy of the area whose values of slope vary between 10 and $15 \%$ and 111,923 inhabitants are installed on grounds whose slopes exceed $15 \%$.

If for Van Caillie (1997), 10-12\% of slopes constitute the minimum threshold for triggering the gully erosion in Kinshasa, Table 2 makes it possible to estimate at 185,000 inhabitants out of 317,690 who live in the zones at risk of gully erosion or landslide. This part of the population accounts for $58.3 \%$ of the population of Selembao as estimated. In other words, more than half of the inhabitants of this Township are exposed to high risk of gully erosion. The districts which shelter the most exposed people at this risk are presented in section 4.2.

\section{Size of Population Based on the Type of Districts}

As Table 2 does not make it possible to see the correlation between the areas at risk of gully erosion (where more than half of the population live) and the types of district, we have also calculated the number of people living in areas at risk of gully erosion depending on the type of districts (Table 3 ).

Table 3 shows the distribution of the population in the Township of Selembao calculated on the basis of homogeneous morphological classes or types of district.

It can be noticed from this table that the spontaneous neighborhoods built on steep areas are home to many more people (either 136,006 out of 303,204 inhabitants) than other neighborhoods. On the other hand, the rich neighborhoods and those that are on ongoing urbanization are less populated. The least populated district are those are built on ground with weak slope and thus at the less risk of gully erosion, as we already pointed it out.

At this level of our investigation, the question which one can wonder about is why the high-risk zones of gully erosion or landslide attract many more individuals. The study of the socio-economic characteristics can make it possible to explain the popular choice of these zones at risk.

\section{Socio-Economic Characteristics of People Living in Areas of high Slopes in Selembao}

From Selembao sample, it can be noticed that the householdsaveragesize is 5.6 persons. In a plot located in poor spontaneous districts, downstream of rich districts, there are about 1.8 households, occupying each one 1 to 2 rooms. The grounds in the plots of rich districts where there are predominantly large villas are concreted, whereas they are cleared out in the poor districts. The proportion of house owners is more or less equal to that of renters ( $49.9 \%$ for the ownersvs $51.1 \%$ for the renters).

Table 2. Population size according to the slope in the township of Selembao

\begin{tabular}{llllll}
\hline $\begin{array}{l}\text { Categories } \\
\text { of slope (\%) }\end{array}$ & $\begin{array}{l}\text { Sampled } \\
\text { Pop (inhab) }\end{array}$ & $\begin{array}{l}\text { Sampled } \\
\text { Area (ha) }\end{array}$ & $\begin{array}{l}\text { Sampleddensity } \\
\text { (inhab/ha) }\end{array}$ & $\begin{array}{l}\text { Occupied } \\
\text { area (ha) }\end{array}$ & Pop \\
\hline$<10$ & 2,827 & 18.019 & 156.888 & 840.224 & 131,821 \\
$10-15$ & 2,417 & 15.779 & 153.177 & 450.101 & 68,945 \\
$>15$ & 2,206 & 13.230 & 166.732 & 701.265 & 116,923 \\
Total & 7,450 & 47.029 & & 1991.592 & 314,690 \\
\hline
\end{tabular}

Legend: Pop $=$ Population number, inhab $=$ inhabitant

Table 3. Population size according to the type of habitat

\begin{tabular}{|c|c|c|c|c|c|}
\hline Morphological classes code & $\begin{array}{l}\text { Sampled } \\
\text { Pop (inhab) }\end{array}$ & $\begin{array}{l}\text { Sampled } \\
\text { area }\left(\mathrm{m}^{2}\right)\end{array}$ & $\begin{array}{l}\text { Sampled density } \\
\text { (inhab/ha) }\end{array}$ & $\begin{array}{l}\text { Occupied } \\
\text { area (ha) }\end{array}$ & Pop \\
\hline 311 & 2,647 & 98566.83 & 268.54 & 260.27 & 69,895 \\
\hline $\begin{array}{l}\text { Old neighborhoods densely built on the top of the hill } \\
211 \\
\text { Rich neighborhoods }\end{array}$ & 1,337 & 158279.19 & 84.47 & 354.98 & 29,986 \\
\hline $\begin{array}{l}\text { Rich neighborhoods } \\
332 \\
\text { Spontaneous settlements on steep slopes }\end{array}$ & 1,464 & 58718.88 & 249.32 & 545.50 & 136,006 \\
\hline $\begin{array}{l}112 \\
\text { Self-built neighborhoods on ongoing urbanization }\end{array}$ & 1,360 & 94962.92 & 143.21 & 357.21 & 51,157 \\
\hline $\begin{array}{l}222 \\
\text { Quarters in the process of densification }\end{array}$ & 642 & 59703.45 & 107.53 & 150.28 & 16,160 \\
\hline Total & 7,450 & 470231.27 & & 1668.25 & 303,204 \\
\hline
\end{tabular}

Legend: Pop $=$ Population number; inhab $=$ inhabitant 
Table 4. Profession and level of studies

\begin{tabular}{|c|c|c|c|c|c|c|}
\hline $\begin{array}{l}\text { CTIP-3niv/A three-level international } \\
\text { classification of jobs type }\end{array}$ & $\begin{array}{l}\text { Primary } \\
\text { school } \\
\text { certificate }\end{array}$ & $\begin{array}{l}\text { Vocational } \\
\text { Diploma }\end{array}$ & $\begin{array}{l}\text { "State Diploma" } \\
\text { (School leaving } \\
\text { certificate) }\end{array}$ & $\begin{array}{l}\text { Undergraduate } \\
\text { Degree }\end{array}$ & $\begin{array}{l}\text { Graduate } \\
\text { Degree }\end{array}$ & Total \\
\hline Trade (Business) workers & 1 & 0 & 0 & 0 & 0 & 1 \\
\hline Farmers, subsistence & 1 & 0 & 0 & 1 & 0 & 2 \\
\hline $\begin{array}{l}\text { Architects, planners, surveyors or geometers and } \\
\text { designers }\end{array}$ & 0 & 0 & 0 & 0 & 1 & 1 \\
\hline Other skilled industrial trades and crafts & 1 & 0 & 1 & 1 & 0 & 3 \\
\hline Hairdressers, beauticians and related workers & 1 & 0 & 0 & 0 & 0 & 1 \\
\hline Drivers of automobiles, light trucks and motorcycles & 5 & 0 & 4 & 0 & 0 & 9 \\
\hline Cooks & 1 & 0 & 1 & 0 & 0 & 2 \\
\hline Directors and managers, retail and wholesale & 0 & 0 & 4 & 0 & 0 & 4 \\
\hline Office workers, General functions & 1 & 0 & 9 & 10 & 3 & 23 \\
\hline Lawyers & 0 & 0 & 0 & 0 & 1 & 1 \\
\hline $\begin{array}{l}\text { Car and windows washers, washers of } \\
\text { linen and other hand washers }\end{array}$ & 1 & 0 & 0 & 0 & 0 & 1 \\
\hline Mechanics and machines repairers & 0 & 0 & 3 & 1 & 0 & 4 \\
\hline The Skilled jobbers in clothing and assimilated ones & 0 & 0 & 3 & 0 & 0 & 3 \\
\hline $\begin{array}{l}\text { The skilled jobbers in building and } \\
\text { assimilated ones }\end{array}$ & 6 & 0 & 4 & 0 & 0 & 10 \\
\hline $\begin{array}{l}\text { The skilled jobbers in woodworking, } \\
\text { woodworkers and assimilated ones }\end{array}$ & 0 & 0 & 2 & 0 & 0 & 2 \\
\hline Safety and security agency workers & 0 & 0 & 3 & 1 & 1 & 5 \\
\hline $\begin{array}{l}\text { Practitioners of traditional medicines and } \\
\text { complementary medicines }\end{array}$ & 0 & 1 & 0 & 0 & 0 & 1 \\
\hline Teachers, secondary school education & 0 & 0 & 0 & 1 & 1 & 2 \\
\hline Database and computer network Specialists & 0 & 0 & 0 & 0 & 1 & 1 \\
\hline Finance Specialists & 0 & 0 & 0 & 1 & 0 & 1 \\
\hline Technical Engineering (except electronics) & 0 & 0 & 0 & 1 & 1 & 2 \\
\hline $\begin{array}{l}\text { Technical engineers of physical and other } \\
\text { technical subjects }\end{array}$ & 0 & 0 & 2 & 1 & 0 & 3 \\
\hline $\begin{array}{l}\text { Market Sellers and door-to-door salesmen } \\
\text { of edible goods }\end{array}$ & 10 & 0 & 12 & 5 & 1 & 40 \\
\hline In actives & 5 & & & 12 & 11 & 30 \\
\hline No answers & 6 & 0 & 11 & 1 & 1 & 19 \\
\hline General total & 36 & 1 & 57 & 36 & 21 & 151 \\
\hline
\end{tabular}

Concerning businesses that different households do, we can identify three dominant lines of activities in the township of Selembao: trade (26.5\%); Handicrafts (skilled and unskilled) (13.2\%) and office jobs (15.2\%). Thus we observe the predominance of merchants and sellers among activities performed within the district of Selembao. (Public) Office workers come secondly. Last is the category of skilled jobbers in building, handicrafts traders and drivers, which are coming up little by little.

By comparing the level of education and the activity carried on by the heads of household (Table 4), one can notice that about half of the respondents completed high school and in majority they do small businesses (seller at the markets and street traders selling food stuff);about $26 \%$ of respondents completed primary school studies. This group dominates the sector of unqualified handicraft jobbers in the building industry. They are self-made bricklayers. Those who completed undergraduate year's studies (approximately 20\%) and those who completed graduate year's studies (approximately 10\%) are office workers or work in the servicing sector requiring a high qualification (such as data processing, architecture, finance, education). But they are often led to deal with smaller jobs, for lack of better opportunities. For example, they become sellers of food stuff (one such case was found) or guardian (another such case was found).

Apart from all these categories of workers there is good portion of unemployed people (18.54\%), whether qualified or not.

\section{Discussion}

The two methods of the population estimation used give different results $(314,690$ and 303,204 inhabitants in Tables 2 and 3). These two results are higher than the official figure of Selembao Township (243,932 inhabitants in 2010), but lower than the figure for the same Township put forward by the Congolese government through the Ministry of Planning in 2004: 335,581 (DSRP, 2005). This confirms the problem of reliable population statistics in developing countries.

As we lack reliable demographic data to validate our results, we have compared the relative error calculated on the basis of the official figures found in the annual report of Selembao Township in 2010. 
Table 5. Sources of income of informants compared to the city average

\begin{tabular}{lll}
\hline Sources of income & Kinshasa* (\%) & Our sample (\%) \\
\hline Informal sector & 89.5 & 51.7 \\
Public sector & 6.1 & 15.2 \\
Formal private sector & 4.4 & 13.2 \\
In actives & 0 & 19.9 \\
Total & 100 & 100 \\
\hline
\end{tabular}

*Source: UNDP (2009)

The population estimation made on the basis of districts type (or morphologically homogeneous classes) has a lower relative error (about 24\%) than the other method error (about 30\%). We can conclude that the population estimation amounting to 300,300 inhabitants in Selembao in 2010 is acceptable.

Concerning socio-economic characteristics, the Selembao households size (5.6 persons) is lower than that of poor households in Kinshasa (7.3 persons), but higher than the non-poor households (5.0 persons) (UNDP, 2009). The proportion of homeowners is more or less equal to that of renters. Due to the lack of data on the percentage of homeowners for the city of Kinshasa, the proportion of homeowners in Selembao was compared to that of Kisenso and KimbansekeTownships, which have relatively similar socio-economic level. The percentage of homeowners in Selembao is lower (49.9\%) than that observed in Kisenso (67\%) and Kimbanseke (67\%) (De Herdt and Marysse, 2006).

Subsequently, it has been interesting to compare the data concerning the source of income of Selembao informants with those found for the city of Kinshasa. These data are provided in Table 5.

By considering the sources of income of informants compared to the city average income (Table 5), it emerges that the proportion of informants, whose source of income is the informal sector, is lower than the city average for the same category of people. On the contrary, informants whose source of income is the public and formal private sectors have a higher proportion than the average proportion of the city for the same category of people. The proportion of informants from the trade sector in Selembao (Table 4) demonstrates the narrowness of formal gainful employment market in Kinshasa and confirms the findings of several researchers that more than half of Congolese households (out)live thanks to informal economy (De Herdt, 2004; Ngunu Kasai, 2004).

Since more than half of households find their income from door-to-door sale or in markets, these households dwell in neighborhoods where the rent is adapted to their means or they buy plots where the land price is low. Now it is in neighborhoods built in areas of steep slopes that the rent or land prices are low (Lelo Nzuzi, 2008). In hazardous area, a plot is sold at (US) $\$ 8$ per $\mathrm{m}^{2}$, while it is (US) $\$ 125$ per $\mathrm{m}^{2}$ in the landscaped area and (US) $\$$ 400-600 per $\mathrm{m}^{2}$ downtown (Lelo Nzuzi, 2011). So those are the more attractive areas to these households despite the risk they represent.

\section{Conclusion}

The size of the population of Selembao was estimated to 300,300 inhabitants in 2010 thanks to a methodology combining remote sensing, GIS and field survey. The proportion of people living in areas at high risk of gully erosion represents approximately $58.3 \%$ of the total population. They inhabit informal settlements built on land with slopes exceeding $10 \%$. They belong mostly to lower socio-economic groups (self-made bricklayers, seller at the markets and street traders selling food stuff) and completed primary school studies.

The level and nature of the income of these modest socio-economic groups are such that they adopt residential integration strategies restricted to marginal areas where land prices and rents are more attractive.

The neighborhoods of middle and upper classes inhabit the low slope areas (slope $<10 \%)$ and thus at less risk of gully erosion. They completed undergraduate year's studies (approximately 20\%) and graduate year's studies (approximately 10\%) and they are office workers or work in the servicing sector requiring a high qualification.

\section{Acknowledgement}

We are grateful to Project Kin-Erosion of University of Kinshasa (UNIKIN) for their materials support and satellite imagery and to all students of Geography Department (UNIKIN) who help us to get data through field surveys.

\section{Author's Contributions}

Each author contributed equally in the preparation, development and publication of this manuscript.

\section{Ethics}

This article is original and contains unpublished material. We confirm that all authors have read and approved the manuscript and there are no conflicts of interest. 


\section{References}

Baudot, Y., 1993. Applications of remote sensing to urban population estimation: A case study of Marrakech, Morocco. EaRSEL Adv. Remote Sens., 2: 138-149.

De Herdt, T., 2004. L'évolution de la pauvreté monétaire à Kisenso entre 1997-2002. Que pouvons-nous dire, ou vaut-il mieux se taire? In Afrique et Développement, 19. Vivre et survivre à Kinshasa. Problématique du développement humain, Observatoire d'économie politique et de développement humain.

De Herdt, T. and S. Marysse, 2006. Mesurer l'impact du fonds social urbain. Analyse comparée de l'évolution socio-économique des communes de Kisenso et de Kimbasenke de 2002 à 2005. IOB, Document de travail, Janvier.

De Saint Moulin, L., 2010. Villes et Organisation de L'espace au Congo (RDC). 1st Edn., Cahier Africains/ L'Harmattan, Paris, ISBN-10: 2296119999, pp: 302.

Delbart, S. and E. Wolff, 2002. Extension urbaine et densité de la population à Kinshasa: Contribution de la télédétection satellitaire. Revue Belge de Géographie (BELGEO), 2: 45-59.

DSRP, 2005. Monograhique de la ville de Kinshasa. 1st Edn., Ministère du Plan, Kinshasa.

Flouriot, J., R. De Maximy and M. Pain, 1975. Atlas de Kinshasa. Institut National du Congo. Bureau d'Etudesd'Aménagements Urbains, Kinshasa.

Hsu, S.H., 1971. Population estimation. Photogrammetric Eng., 37: 449-454.

Kayembe wa Kayembe, M., 2012. Les dimensions sociospatiales de l'érosion ravinante intra-urbaine dans une ville tropicale humide. Le cas de Kinshasa (R.D. Congo). Thèse de doctorat, Université Libre de Bruxelles.

Kayembe wa Kayembe, M., M. De Maeyer and E. Wolff, 2009. Cartographie de la croissance urbaine de Kinshasa (R.D.Congo) entre 1995 et 2005 par télédétection satellitaire à haute résolution. Revue Belge Géographie (BELGEO), 3-4: 439-455.

Lelo Nzuzi, F., 2011. Kinshasa, Planification et Aménagement. 1st Edn., L'Harmattan, Paris, ISBN-978-2-296-56072-7, pp: 231.

Lelo Nzuzi, F., 2008. Kinshasa, ville et Environnement. 1 st Edn., L'Harmattan, Paris, ISBN-978-2-296-06080-7, pp: 125.

Lo, C.P., 1985. Automated population and dwelling unit estimation from high-resolution satellite images : A GIS approach. International Journal of Remote Sensing, 16, 1: 17-34.
Lu, A.M., C.M. Li and Z.J. Lin, 2002. Modeling middle urban population density with remote sensing imagery. Symposium on Geospatial Theory, Processing and Applications, Ottawa.

Makanzu Imwangana, F., I. Vandecasteele, P. Ozer, P. Trefois and J. Moeyersons, 2015. The origin and control of mega-gullies in Kinshasa (D.R. Congo). Catena, 125: 38-49.

DOI: 10.1016/j.catena.2014.09.019

Makanzu Imwangana, F., O. Dewitte, M. Ntombi and J. Moeyersons, 2014. Topographic and road control of mega-gullies in Kinshasa (DR Congo). Geomorphology, 207 : 131-139. DOI: 10.1016/j.geomorph.2014.04.021

Ngunu Kasai, D.P., 2004. Analyse des mécanismes et stratégies de survie de la population de Kinshasa. Cas des Boutiques et Ligblos. In Afrique et Développement, 19, Vivre et survivre à Kinshasa. Problématique du développement humain.

POPSATER, 2011. Rapport final.

Romaniuk, A., 1967. La Fécondité des Populations Congolaises. 1st Edn., Mouton and compagnie et IRES, Paris, pp: 352.

UNDP, 2009. Province de Kinshasa. Pauvreté et conditions de vie des ménages.

Van Caillie, X., 1997. La carte des pentes (1/20 000) de la région des collines à Kinshasa. Réseau Erosion ORSTOM, 17: 198-204.

Watkins, J.F. and J. Morrow, 1985. Small area population estimates using aerial photography. Photogrammetric Eng. Remote Sens., 51: 1933-1935.

Wouters, T. and E. Wolff, 2010. Contribution à l'analyse de l'érosion intra-urbaine à Kinshasa (R.D.C.). Revue Belge Géographie (BELGEO), 3: 293-314. DOI: $10.4000 /$ belgeo.6477

Yagoub, M.M., 2006. Application of remote sensing and Geographic Information Systems (GIS) to population studies in the Gulf: A case of Al Ain City (UAE). J. Ind. Society Remote Sens., 34: 8-21. DOI: 10.1007/BF02990743

Yossi, R.N., E. Tonye, A. Akono and J.P. Rudant, 2002. Apport de la télédétection et de l'imageinterprétation à l'estimation de population de Yaoundé. Télédétection, 3: 249-262. 